\title{
PHYSIOLOGICAL EVALUATION OF WHEAT GENOTYPES FOR TOLERANCE TO WATER DEFICIT STRESS
}

\author{
M. S. Rana*, M. A. Hasan, M. M. Bahadur and M. R. Islam \\ Department of Crop Physiology and Ecology, Hajee Mohammad Danesh Science and Technology University, Dinajpur \\ *Corresponding author, E-mail: sohe10901084@gmail.com
}

(Received: 24 April 2017, Accepted: 7 June 2017)

Keywords: Wheat genotypes, water stress, stress tolerance and yield

\begin{abstract}
Four wheat genotypes (BARI Gom 25, E 28, BAW 1170, BAW1140) were grown under well water and water deficit stress condition to evaluate the sensitivity of physiological traits of wheat resulting reduced grain yield under water deficit stress. Wheat genotypes showed greater stability of flag leaf chlorophyll, greater ability to retain water in leaf, higher level of proline in flag leaf and kernel, higher level of soluble sugar in flag leaf and greater ability to keep the canopy cooler compared to sensitive genotype under water deficit condition. Greater spike dry matter accumulation at peak, longer grain growth duration, better yield components such as spikes $\mathrm{m}^{-2}$ and grains spike $^{-1}$ under water deficit stress contributed to better tolerance of BARI Gom 25, E 28 and BAW 1170. The order of tolerance based on grain yield was BAW $1170>$ BARI Gom $25>$ E $28>$ BAW 1140 and the order of tolerance based on above ground biological yield was BAW $1170>$ E $28>$ BARI Gom $25>$ BAW 1140 .
\end{abstract}

\section{Introduction}

Wheat (Triticum aestivum L.), next to rice is the staple food of the people of Bangladesh grown over an area of 0.45 million hectares with an annual production about 1.35 million metric tons and the average yield $3.03 \mathrm{t} \mathrm{ha}^{-1}$ (BBS, 2016), comparatively low than the other wheat growing countries. Wheat is mainly grown under non-irrigated drought conditions during the winter period (November to April) in Bangladesh though the vast storage of soil moisture resulted from monson rain supports the wheat growth favorably at the early stages but the plant suffers from water stress at the reproductive stages when the residual soil moisture depletes (Karim et al., 2000). Water stress causes a declines in relative water content (RWC), chlorophyll (chl) and carotenoid content, membrane stability and nitrate reductase activity and increases accumulation of abscisic acid (ABA), proline (Chandrasekar et al., 2000), soluble sugar (Kameli and Loesel, 1993) and leaf and canopy temperature. Water deficit reduces the interception of solar radiation in the canopy due to early senescence as well as rolling up the leaves (Muller, 2001). Due to raise in world temperature soil losses it's moisture holding capacity as a result drought effect is accelerated. Thus, the best option for yield improvement and yield stability of wheat under soil moisture deficit condition is to screen or develop drought tolerant wheat varieties and to ameliorate the adverse effect of water deficit stress through agronomic strategies. The application of physiological tolerance with agronomic traits has been used to be applicable and their interaction with water stress tolerance indices are considered strong enough to be exploited as a selection way in the breeding of water stress tolerance cultivars (Allakhverdiev et al., 2000). Therefore, the present study was carried out to expand 
Rana et al.

wheat cultivation and to sustain wheat yield under drought prone area by evaluating the sensitivity of physiological traits of wheat result in reduced grain yield under water deficit stress.

\section{Materials and Methods}

The experiment was set up at the research farm of Crop Physiology and Ecology Department, Hajee Mohammad Danesh Science and Technology University, Dinajpur, Bangladesh during November 2014 to April 2015 located at 2539' N latitude and 8841' E longitude with an elevation of 37.58 meter above the sea level. The experiment was conducted in a split- plot design with three replications. The unit plot size was $2.5 \mathrm{~m} \times 2.0 \mathrm{~m}$. The treatments were A) main plot: two water regimes; irrigations were applied at crown root initiation (CRI), anthesis and grain filling stages and water deficit stress and no irrigation was applied and the crop was protected from rainfall by rainout shelter and B) sub-plot: four wheat genotypes viz. BARI Gom 25, E 28, BAW 1170 and BAW 1140. A fertilizer dose of 140-35-75-18-2-0.5 kg ha-1 N, P, $\mathrm{K}, \mathrm{S}, \mathrm{Zn}$ and B was applied in the form of Urea, Triple Supper phosphate (TSP), Muriate of potash (MoP), Gypsum and Boric acid, respectively. After land preparation, full dose of $\mathrm{P}, \mathrm{K}, \mathrm{S}$, $\mathrm{Zn}, \mathrm{B}$ and two third of $\mathrm{N}$ were incorporated thoroughly into the soil as basal dose. The remaining amount of $\mathrm{N}$ was applied at 25 days after seedlings emergence. Seeds of four wheat genotypes were sown in rows of $20 \mathrm{~cm}$ apart, at the rate of $120 \mathrm{~kg} \mathrm{ha}^{-1}$. Slight irrigation was given for uniform germination after sowing and other intercultural operations were done as per requirement.

\section{Physiological traits}

\section{Spike dry matter accumulation}

At anthesis 80 main shoots were tagged from each plot. Four tagged main shoot spikes were harvested at every $4^{\text {th }}$ day beginning from anthesis to quantify spike dry matter accumulation pattern. Collection of main shoot spike in all genotypes was continued up to 40 days after anthesis (DAA) for both well watered and water deficit stress condition. The harvested spikes were kept in oven at $70^{\circ} \mathrm{C}$ for 72 hours. After oven drying, spikes were weighted with an analytical balance (AND Electronic Balance Model EK 300 i).

\section{Estimation of proline}

Proline content of flag leaf and kernel at 16 DAA of wheat genotypes grown in two growing conditions were estimated according to Bates (1973) from a standard curve and calculated on a fresh weight basis as follows:

$\mu$ moles proline $/ \mathrm{g}$ of fresh plant material $=\{(\mu \mathrm{g}$ proline $/ \mathrm{ml} \times \mathrm{ml}$ toluene $) / 115.5 \mu \mathrm{g} /$ $\mu$ moles\} / (g sample/5)

\section{Estimation of soluble sugar}

The soluble sugar content of flag leaf collected at 16 DAA of wheat genotypes were determined as Yoshida et al. (1976) using standard curve.

\section{Estimation of chlorophyll}

Total chl content of the flag leaf at 8 and 24 days after anthesis was estimated according to Witham et al. (1986) using following formula-

Total chl $\left(\mathrm{mg} \mathrm{g}^{-1} \mathrm{FW}\right)=\left[20.2\left(\mathrm{D}_{645}\right)+8.02\left(\mathrm{D}_{663}\right)\right] \times[\mathrm{V} /(1000 \times \mathrm{W})]$ 
Physiological Evaluation of Wheat Genotypes for Tolerance

(Where, $\mathrm{V}=$ Volume of $80 \%$ aqueous acetone $(\mathrm{ml}), \mathrm{W}=$ Weight of fresh leaf $(\mathrm{g})$, $\mathrm{D}_{645}=$ Absorbance at $645 \mathrm{~nm}$ wavelength and $\mathrm{D}_{663}=$ Absorbance at $663 \mathrm{~nm}$ wavelength)

Leaf relative water content (LRWC)

Relative flag leaf water content was determined at 16 DAA from the equation of Schonfeld et al. (1988).

RLWC $(\%)=\{($ Fresh weight - Dry weight $) /($ Turgid weight - Dry weight $)\} \times 100$

\section{Canopy temperature Depression (CTD)}

The hand held infra-red thermometer (Model: Crop TRACK item no. 2955L-Spectrum Tecnologies, Inc.) was used to measure the CTD at 8 and 24 DAA during noon period under bright sunlight and less wind conditions.

\section{Agronomical traits}

Plant height, spike length (excluding awn), number of grains spike-1, Number of spikes $\mathrm{m}^{-2}$, grain yield $\mathrm{m}^{-2}$, straw yield $\mathrm{m}^{-2}$, thousand grain weights, grain yield and above ground biological yield of wheat genotypes were taken properly. Grain and above ground biological yield were adjusted to $12 \%$ moisture content.

\section{Stress susceptibility index (SSI)}

Higher SSI indicates greater susceptibility. SSI was calculated for grain yield as described by Fisher and Maurer (1978).

$\mathrm{SSI}=\left(1-\mathrm{Y} / \mathrm{Y}_{\mathrm{p}}\right) /\left(1-\mathrm{X} / \mathrm{X}_{\mathrm{p}}\right)$

(Where, $Y=$ Grain yield of genotype in a stress environment, $Y_{p}=$ Grain yield of genotype in a stress-free environment, $X=$ Mean $Y$ of all genotypes and $X_{p}=$ Mean $Y_{p}$ of all genotypes

\section{Soil moisture content}

The soil samples were collected from desired depths $(15 \mathrm{~cm})$ from several places and were taken in air tight containers. The samples were weighed and then they were dried in an oven at $105^{\circ} \mathrm{C}$ for about 24 hours or till constant weight. The samples were then taken out from oven and weighed again and the loss in weight (Wt.) is the amount of water soil.

Soil moisture content $(\%)=\{($ Wt. of moist sample-Wt. of oven dry sample $) /$ Wt. of oven dry sample\} $\times 100$

\section{Statistical analysis}

The data were analyzed by partitioning the total variance with the help of computer by using MSTAT program. The treatment means were compared using Duncun's Multiple Range Test (DMRT) at $\mathrm{P} \leq 5 \%$ level of significance. Correlation analysis was also done.

\section{Results and Discussion}

\section{Soil moisture content}

Soil moisture content at 0-15 cm depth of well watered and water stressed plots at different days after sowing is presented in Figure 1 which shows that well watered plot maintained higher soil moisture (7.40, 9.27 and 8.89\%) than that of water stressed plot $(4.36,3.87$ and 
Rana et al.

3.30\%) at 90, 100 and 110 days after sowing, respectively. Besides, soil moisture of water stressed plot was reduced gradually with the advancement of time after sowing.

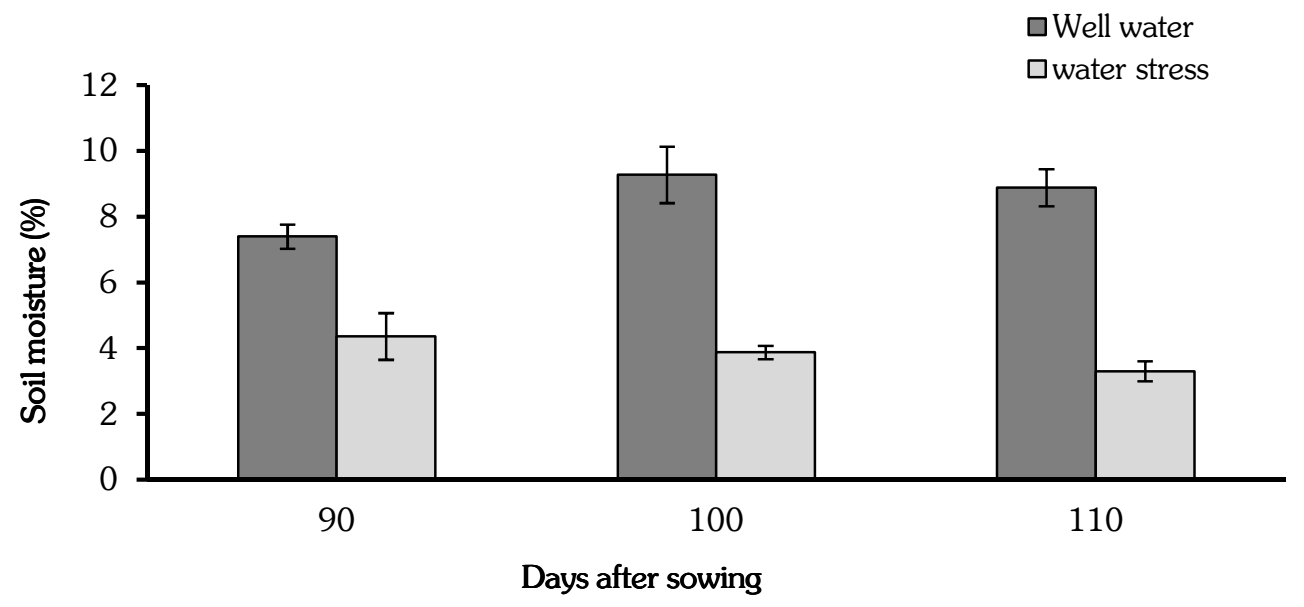

Fig. 1. Soil moisture content $(0-15 \mathrm{~cm}$ depth) at different days after sowing as influenced by water regimes.

\section{Phenological parameters}

Wheat genotypes and water regimes interacted significantly to influence the number of days required to attain anthesis and physiological maturity (Table 1). Under water stress condition, all the wheat genotypes required shorter time (68-76 days) to attain anthesis compared to well water condition (71-79 days). BAW 1170 required maximum days (79 days) under well water condition but anthesis occurred 3 days earlier in this genotype under water stress condition. The genotype E 28 required minimum days (71 days) under well water condition but anthesis occurred 3 days earlier in this genotype under water stress condition. In BARI Gom 25 and BAW 1140 anthesis was 1 and 2 days earlier, respectively under water stress condition compared to well water condition. Under water stress condition, all the wheat genotypes required shorter time (102 -109 days) to attain physiological maturity compared to well water condition (105-110 days). The genotype BAW 1170 and BAW 1140 required maximum days (110 days) under well water condition whereas BAW 1170 attained at physiological maturity 1 days earlier and BAW 1140 attained at physiological mature stage and 6 days earlier under water stress condition. BARI Gom 25 and E 28 required minimum days (105 days) to maturity under well water condition whereas BARI Gom 25 attained at physiological maturity 1 day earlier and E 28 attained at physiological mature stage 3 days earlier under water stress condition. The time required for the phonological development of crops is one of the most important factors for yield adaptation in any environment (Motzo and Giunta, 2007). In principle, the length of growing period and phenological development of crops can affect the yield either by consuming more resources or by decreasing the environmental tensions or by reducing the length of the periods (Attarbashi et al. 2002). In the present study, water deficit stress accelerated anthesis and physiological maturity stage. Similar results were also reported by various researchers that water deficit stress reduced the number of days to anthesis (Kiliç and Yagbasanlar, 2010, Sial et al. 2009, Khakwani et al., 2012) and days to maturity (Kiliç and Yagbasanlar, 2010). 
Physiological Evaluation of Wheat Genotypes for Tolerance

Table 1. Effect of water regimes on days required to attain anthesis and physiological maturity of different wheat genotypes

\begin{tabular}{|c|c|c|c|c|c|}
\hline \multirow[t]{2}{*}{ Wheat genotypes } & \multirow[t]{2}{*}{ Water regimes } & \multicolumn{2}{|c|}{ Days to anthesis } & \multicolumn{2}{|c|}{$\begin{array}{c}\text { Days to physiological } \\
\text { maturity }\end{array}$} \\
\hline & & $\begin{array}{c}\text { Number of } \\
\text { days }\end{array}$ & $\begin{array}{c}\text { Early in } \\
\text { days over } \\
\text { control }\end{array}$ & $\begin{array}{c}\text { Number of } \\
\text { days }\end{array}$ & $\begin{array}{c}\text { Early in } \\
\text { days over } \\
\text { control }\end{array}$ \\
\hline \multirow[t]{2}{*}{ BARI Gom 25} & Well watered & $74 \mathrm{c}$ & - & $105 \mathrm{~b}$ & - \\
\hline & Water stress & $73 d$ & 1 & $104 \mathrm{~b}$ & 1 \\
\hline \multirow[t]{2}{*}{ E 28} & Well watered & $71 e$ & - & $105 \mathrm{~b}$ & - \\
\hline & Water stress & $68 \mathrm{f}$ & 3 & $102 \mathrm{c}$ & 3 \\
\hline \multirow[t]{2}{*}{ BAW 1170} & Well watered & $79 a$ & - & $110 \mathrm{a}$ & - \\
\hline & Water stress & $76 \mathrm{~b}$ & 3 & $109 a$ & 1 \\
\hline \multirow[t]{2}{*}{ BAW 1140} & Well watered & $72 \mathrm{~d}$ & - & $110 \mathrm{a}$ & - \\
\hline & Water stress & $70 e$ & 2 & $104 \mathrm{~b}$ & 6 \\
\hline \multicolumn{2}{|c|}{ Level of significance } & $*$ & & $* *$ & \\
\hline \multicolumn{2}{|c|}{$\mathrm{CV}(\%)$} & 0.48 & & 1.04 & \\
\hline
\end{tabular}

In a column, values followed by similar letter(s) did not differ significantly by DMRT at $\mathrm{P} \leq 5 \%$

\section{Physiological traits}

\section{Flag leaf chlorophyll content}

Flag leaf chl content at 8 days after anthesis (DAA) was significantly influenced by the interaction effect of wheat genotypes and water regimes (Table 2). Under water stress condition, flag leaf chl was increased by 8.12\% in BARI Gom 25, 7.65\% in BAW 1170 and $5.37 \%$ in BAW 1140 whereas it was same both at well water and water stress condition in $\mathrm{E}$ 28. Flag leaf chl content at 24 days after anthesis (DAA) was also influenced significantly by the combined effect of wheat genotypes and water regimes (Table 2). Due to water stress condition, all the wheat genotypes showed lower flag leaf chl content $\left(0.88-1.39 \mathrm{mg} \mathrm{chl} \mathrm{g}^{-1} \mathrm{FW}\right)$ compared to well water condition (1.24-1.44 mg chl g-1FW). But the degree of reduction was not same for all wheat genotypes. Under water stress condition, flag leaf chl was reduced by $13.88 \%$ in BARI Gom 25, 22.65\% in E 28, 3.47\% in BAW 1170 and $29.03 \%$ in BAW 1140.

Chlorophyll content has been known as an index for evaluation of source, therefore decrease in leaf chl content can be considered as a non- stomatal limiting factor in the drought stress conditions (Herzog, 1986). In the present study, flag leaf chl content at 8 days after anthesis remained same or increased under water stress condition, it might be due to the support of the vast storage of soil moisture resulted from monsoon (Karim et al., 2000). Deora et al. (2001) also reported that chl content in wheat increased in stressed leaves as compared to normal leaves. Flag leaf chl content at 24 days after anthesis was reduced due to water stress, as the plant suffers from severe water stress at this stage when the residual soil moisture depletes. The sensitive genotype BAW 1140 was found to affect more than the tolerant genotypes (BARI Gom 25, E 28 and BAW 1170) in chl degradation.

Farshadfar et al. (2014) working with what genotypes also reported that water stress reduced chl content and the reduction was more pronounced in drought susceptible genotypes. 
Rana et al.

Table 2. Effect of water regimes on different physiological traits of wheat

\begin{tabular}{|c|c|c|c|c|c|c|c|c|c|}
\hline \multirow{3}{*}{$\begin{array}{c}\text { Wheat } \\
\text { genotypes }\end{array}$} & \multirow{3}{*}{$\begin{array}{l}\text { Water } \\
\text { levels }\end{array}$} & \multicolumn{4}{|c|}{ Flag leaf chlorophyll content } & \multicolumn{4}{|c|}{ Canopy temperature depression } \\
\hline & & \multicolumn{2}{|c|}{ At 8 DAA } & \multicolumn{2}{|c|}{ At 24 DAA } & \multicolumn{2}{|c|}{ At 8 DAA } & \multicolumn{2}{|c|}{ At 24 DAA } \\
\hline & & $\begin{array}{l}\mathrm{mg} \mathrm{g}^{-1} \\
\mathrm{FW}\end{array}$ & $\begin{array}{c}\% \\
\text { change } \\
\text { over } \\
\text { control }\end{array}$ & $\begin{array}{c}\mathrm{mg} \mathrm{g}^{-1} \\
\mathrm{FW}\end{array}$ & $\begin{array}{c}\% \\
\text { change } \\
\text { over } \\
\text { control }\end{array}$ & ${ }^{\circ} \mathrm{C}$ & $\begin{array}{c}\% \\
\text { change } \\
\text { over } \\
\text { control }\end{array}$ & ${ }^{\circ} \mathrm{C}$ & $\begin{array}{c}\% \\
\text { change } \\
\text { over } \\
\text { control }\end{array}$ \\
\hline \multirow[t]{2}{*}{$\begin{array}{l}\text { BARI } \\
\text { Gom } 25\end{array}$} & $\begin{array}{l}\text { Well } \\
\text { watered }\end{array}$ & $1.60 \mathrm{c}$ & - & $1.44 \mathrm{a}$ & - & 8.05 & - & $4.93 \mathrm{~b}$ & - \\
\hline & $\begin{array}{l}\text { Water } \\
\text { stress }\end{array}$ & $1.73 \mathrm{bc}$ & +8.12 & $1.24 \mathrm{a}$ & -13.88 & 7.50 & -6.83 & $3.44 \mathrm{~d}$ & -30.22 \\
\hline \multirow[t]{2}{*}{ E 28} & $\begin{array}{l}\text { Well } \\
\text { watered }\end{array}$ & $1.84 \mathrm{~b}$ & - & $1.28 \mathrm{a}$ & - & 8.46 & - & $4.74 \mathrm{~b}$ & - \\
\hline & $\begin{array}{l}\text { Water } \\
\text { stress }\end{array}$ & $1.84 \mathrm{~b}$ & 0.0 & $0.99 \mathrm{~b}$ & -22.65 & 7.60 & -10.16 & $3.18 \mathrm{~d}$ & -32.91 \\
\hline \multirow{2}{*}{$\begin{array}{l}\text { BAW } \\
1170\end{array}$} & Well & $1.96 \mathrm{ab}$ & - & $1.44 \mathrm{a}$ & - & 8.86 & - & $4.16 \mathrm{c}$ & - \\
\hline & $\begin{array}{l}\text { Water } \\
\text { stress }\end{array}$ & $2.11 \mathrm{a}$ & +7.65 & $1.39 \mathrm{a}$ & -3.47 & 7.48 & -15.57 & $3.50 \mathrm{~d}$ & -15.86 \\
\hline \multirow{2}{*}{$\begin{array}{l}\text { BAW } \\
1140\end{array}$} & Well & $1.86 \mathrm{~b}$ & - & $1.24 \mathrm{a}$ & - & 7.62 & - & $5.62 \mathrm{a}$ & - \\
\hline & $\begin{array}{l}\text { Water } \\
\text { stress }\end{array}$ & $1.96 \mathrm{ab}$ & +5.37 & $0.88 \mathrm{~b}$ & -29.03 & 7.49 & -1.71 & $3.60 \mathrm{~cd}$ & -35.94 \\
\hline \multicolumn{2}{|c|}{ Level of significance } & $\begin{array}{c}* * * \\
669\end{array}$ & & $\begin{array}{c}* * * \\
815\end{array}$ & & $\begin{array}{l}\text { NS } \\
517\end{array}$ & & $\begin{array}{c}* * * \\
445\end{array}$ & \\
\hline
\end{tabular}

In a column, values followed by similar letter(s) did not differ significantly by DMRT at $\mathrm{P} \leq 5 \%$

\section{Canopy temperature depression (CTD)}

Canopy temperature depression at 8 days after anthesis was not influenced significantly by the interaction effect of wheat genotypes and water regimes but at 24 days after anthesis it was influenced significantly by the interaction effect of wheat genotypes and water regimes (Table 2). At 24 days after anthesis, all the wheat genotypes maintained higher CTD (4.16$\left.5.62^{\circ} \mathrm{C}\right)$ under well water condition compared to that $\left(3.18-3.60^{\circ} \mathrm{C}\right)$ under water stress condition. CTD was reduced by $30.22 \%$ in BARI Gom 25, 32.91\% in E 28, 15.86\% in BAW 1170 and 35.94\% in BAW 1140.

The results indicated that the tolerant genotypes maintained comparatively a cooler canopy under water deficit stress compared to the sensitive genotype. Buttar et al. (2005), and Lopes and Reynolds (2010) also reported higher canopy temperature in stressed wheat compared to non- stressed wheat. Relatively lower canopy temperature in drought stressed crop plants indicates a relatively better capacity for taking up soil moisture and for maintaining a relatively better plant water status by various plant adaptive traits (Blum et al., 1989).

\section{Relative water content of flag leaf}

Relative leaf water content of flag leaf at 16 days after anthesis was significantly influenced by the interaction effect of wheat genotypes and water levels (Table 3). At well watered condition, the maximum flag leaf water content was found in BAW 1140 (83.84\%) which was followed 
by BAW 1170 (80.96\%) and BARI Gom 25(80.72\%) while E 28 showed the lowest relative leaf water content $(80.42 \%)$. Under water stress condition, all the wheat genotypes showed lower relative leaf water content compared to well water condition except BARI Gom 25 in which the relative leaf water content was even increased by $2.15 \%$. Among the other three genotypes BAW 1140 affected more (3.57\%) than E 28 (1.24\%) and BAW 1170 (3.24\%) in reducing leaf water content.

Reduction in the relative water content due to drought stress has been noted in wide variety of plants as reported by Nayyar and Gupta (2006), Farshadfar et al. (2012), Hasheminasab et al. (2012) and Farshadfar et al. (2014) also reported relative water content as a useful character for selecting drought tolerant wheat genotypes.

\section{Flag leaf and kernel proline content}

Wheat genotypes and water regimes interacted significantly to influence flag leaf and kernel proline content at 16 days after anthesis (Table 3). Under well condition, BARI Gom 25 contained the highest amount of proline in flag leaf $\left(11.98 \mu\right.$ mole $\left.\mathrm{g}^{-1} \mathrm{FW}\right)$ which was followed by E 28 (10.28 $\mu$ mole $\left.\mathrm{g}^{-1} \mathrm{FW}\right)$ and BAW $1170\left(9.95 \mu\right.$ mole $\left.^{-1} \mathrm{FW}\right)$ while BAW 1140 contained the lowest amount of proline in flag leaf $\left(9.76\right.$ mole $\left.\mathrm{g}^{-1} \mathrm{FW}\right)$.Under water stress condition, flag leaf proline was increased by 1 to $5.35 \%$ in three tolerant genotypes (BARI Gom 25, E 28 and BAW 1170) whereas the flag leaf proline was reduced by $5.84 \%$ in sensitive genotype (BAW 1140) compared to well water condition.

Under well condition, BAW 1140 and BAW 1170 contained the highest amount of proline in kernel leaf (21.38 mole $\left.\mathrm{g}^{-1} \mathrm{FW}\right)$ which was followed by BARI Gom 25 (20.73 $\mu$ mole $\left.{ }^{-1} \mathrm{FW}\right)$ whereas E 28 contained the lowest amount of proline in kernel $\left(17.21 \mu\right.$ mole $\left.^{-1} \mathrm{FW}\right)$ at 16 days after anthesis. Under water stress condition, kernel proline was increased by $1.39 \%$ in BARI Gom 25 and 1.10\% in E 28. BAW 1170 and BAW 1140 failed to accumulate enough quantity of proline in kernel to tolerate water deficit stress. The kernel proline was reduced by $13.98 \%$ in BAW 1170 and 26.65\% in sensitive genotype (BAW 1140) compared to well water condition.

Plants accumulate proline in large quantities in response to environmental stresses. Accumulation of proline under stress in many plant species has been correlated with stress tolerance, and its concentration has been known to be usually higher in stress tolerant than in stress sensitive plants. High levels of proline enable a plant to maintain low water potentials. Aggarwal et al., (2011) reported that proline provides tolerance against different abiotic stresses by increasing their endogenous level and their intermediate enzymes in plants and osmotically stressful conditions (Bayoumi et al., 2008).

\section{Flag leaf soluble sugar content}

Soluble sugar content in flag leaf at 16 days after anthesis was influenced significantly by the combined effect of wheat genotypes and water regimes (Table 3). Under well condition, E 28 contained the highest amount of soluble sugar in flag leaf $\left(61.02 \mathrm{mg} \mathrm{g}^{-1} \mathrm{DW}\right)$ which was followed by BAW 1170 (54.04 $\mathrm{mg} \mathrm{g}^{-1} \mathrm{DW}$ ) and BAW 1140 (51.13 $\left.\mathrm{mg} \mathrm{g}^{-1} \mathrm{DW}\right)$ whereas BARI Gom 25 contained the lowest amount of soluble sugar in flag leaf $\left(48.40 \mathrm{mg} \mathrm{g}^{-1} \mathrm{DW}\right)$. Under water stress condition, flag leaf soluble sugar was increased by 2.96 to $25.42 \%$ in three tolerant genotypes (BARI Gom 25, E 28 and BAW 1170) whereas the flag leaf soluble sugar was reduced by $9.63 \%$ in sensitive genotype (BAW 1140) compared to well water condition. 
Rana et al.

Sugars produced during photosynthesis play a significant role in plant growth and development under abiotic stresses by regulating carbohydrate metabolism. Siddique et al. (2000) reported that adaptation to water stress has been attributed to the stress induced increase in sugar levels.

Table 3. Effect of water regimes on different physiological traits of wheat

\begin{tabular}{|c|c|c|c|c|c|c|c|c|c|}
\hline \multirow[t]{2}{*}{$\begin{array}{l}\text { Wheat } \\
\text { genotypes }\end{array}$} & \multirow[t]{2}{*}{$\begin{array}{l}\text { Water } \\
\text { levels }\end{array}$} & \multicolumn{2}{|c|}{$\begin{array}{c}\text { Relative leaf water } \\
\text { content at } 16 \text { DAA }\end{array}$} & \multicolumn{2}{|c|}{$\begin{array}{c}\text { Flag leaf proline } \\
\text { content at } 16 \text { DAA }\end{array}$} & \multicolumn{2}{|c|}{$\begin{array}{c}\text { Kernel proline } \\
\text { content at } 16 \text { DAA }\end{array}$} & \multicolumn{2}{|c|}{$\begin{array}{l}\text { Flag leaf soluble } \\
\text { sugar at } 16 \text { DAA }\end{array}$} \\
\hline & & $\%$ & $\begin{array}{c}\% \\
\text { change } \\
\text { over } \\
\text { control }\end{array}$ & $\begin{array}{c}\mathrm{mol} \\
\mathrm{g}^{-1} \mathrm{FW}\end{array}$ & $\begin{array}{c}\% \\
\text { change } \\
\text { over } \\
\text { control }\end{array}$ & $\begin{array}{c}\mathrm{mol} \\
\mathrm{g}^{-1} \mathrm{FW}\end{array}$ & $\begin{array}{c}\% \\
\text { change } \\
\text { over } \\
\text { control }\end{array}$ & $\begin{array}{l}\mathrm{mg} \mathrm{g}^{-1} \\
\mathrm{DW}\end{array}$ & $\begin{array}{c}\% \\
\text { change } \\
\text { over } \\
\text { control }\end{array}$ \\
\hline \multirow[t]{2}{*}{$\begin{array}{l}\text { BARI } \\
\text { Gom } 25\end{array}$} & $\begin{array}{l}\text { Well } \\
\text { watered }\end{array}$ & $80.72 \mathrm{~b}$ & - & $11.98 \mathrm{~b}$ & - & $20.73 \mathrm{~b}$ & - & $48.40 \mathrm{~cd}$ & - \\
\hline & $\begin{array}{l}\text { Water } \\
\text { Istress }\end{array}$ & $82.87 \mathrm{a}$ & +2.15 & $12.62 \mathrm{a}$ & +5.34 & $21.02 b$ & +1.39 & $60.70 \mathrm{~b}$ & +25.42 \\
\hline \multirow[t]{2}{*}{ Е 28} & $\begin{array}{l}\text { Well } \\
\text { watered }\end{array}$ & $80.42 \mathrm{~b}$ & - & $10.28 \mathrm{~d}$ & - & $17.21 \mathrm{c}$ & - & $61.02 \mathrm{~b}$ & - \\
\hline & $\begin{array}{l}\text { Water } \\
\text { stress }\end{array}$ & $79.42 \mathrm{c}$ & -1.24 & $10.83 c$ & +5.35 & $17.40 \mathrm{c}$ & +1.10 & $69.24 \mathrm{a}$ & +13.45 \\
\hline \multirow[t]{2}{*}{$\begin{array}{l}\text { BAW } \\
1170\end{array}$} & $\begin{array}{l}\text { Well } \\
\text { watered }\end{array}$ & $80.96 b$ & - & $9.95 \mathrm{~d}$ & - & $21.38 \mathrm{a}$ & - & $54.04 \mathrm{bd}$ & - \\
\hline & $\begin{array}{l}\text { Water } \\
\text { stress }\end{array}$ & $78.33 c$ & -3.24 & $10.05 \mathrm{~d}$ & +1.00 & $18.39 \mathrm{c}$ & -2.99 & $55.64 \mathrm{bc}$ & +2.96 \\
\hline \multirow[t]{2}{*}{$\begin{array}{l}\text { BAW } \\
1140\end{array}$} & $\begin{array}{l}\text { Well } \\
\text { watered }\end{array}$ & $83.84 \mathrm{a}$ & - & $9.76 \mathrm{~d}$ & - & $21.38 \mathrm{a}$ & - & $51.13 \mathrm{~cd}$ & - \\
\hline & $\begin{array}{l}\text { Water } \\
\text { stress }\end{array}$ & $80.84 \mathrm{~b}$ & -3.57 & $9.19 e$ & -0.57 & $15.70 \mathrm{~d}$ & -5.68 & $46.40 \mathrm{~d}$ & -9.63 \\
\hline \multicolumn{2}{|c|}{ Level of significance } & *** & & * & & *** & & ${ }^{*}$ & \\
\hline CV (\%) & & 1.03 & & 2.87 & & 3.37 & & 7.53 & \\
\hline
\end{tabular}

In a column, values followed by similar letter(s) did not differ significantly by DMRT at $\mathrm{P} \leq 5 \%$

\section{Spike dry matter accumulation}

Both under well water and water deficit stress condition, a typical sigmoid pattern of dry matter accumulation in spikes were found in all wheat genotypes (Figure 2). Under well water condition, the spike dry weight was observed to be increased up to $2.64 \mathrm{~g}$ at $36 \mathrm{DAA}$ in BARI Gom 25, $2.47 \mathrm{~g}$ at 40 DAA in E 28, $2.45 \mathrm{~g}$ at 40 DAA in BAW 1170 and $2.68 \mathrm{~g}$ at 40 DAA in BAW 1140 and decline thereafter slowly. Under water deficit stress condition, maximum dry matter accumulation in spike was reduced in all wheat genotypes except in E 28 and days required to attain maximum dry weight were reduced in all genotypes except BAW 1170.The reduction in maximum spike dry weight were lower in tolerant wheat genotypes $17.58 \%$ in BARI Gom 25, 0.0\% in E 28 and 10.61\% in BAW1170) compared to that in sensitive genotype (19.03\% in BAW 1140). Number of days required to attain maximum dry weight were reduced by o to 4 days in tolerant genotypes (BARI Gom 25, E 28 and BAW1170) but it was 8 days in sensitive wheat genotype (BAW 1140). After attaining the highest level in spike dry matter, the reduction could be due to respiratory loss of spike. Thus it indicated the importance of harvesting the crop and quickly drying the wheat grains when it attain at 
physiological maturity. Similar pattern of spike dry matter accumulation in wheat was also found by Hasan et al. (2007) under heat stress condition.
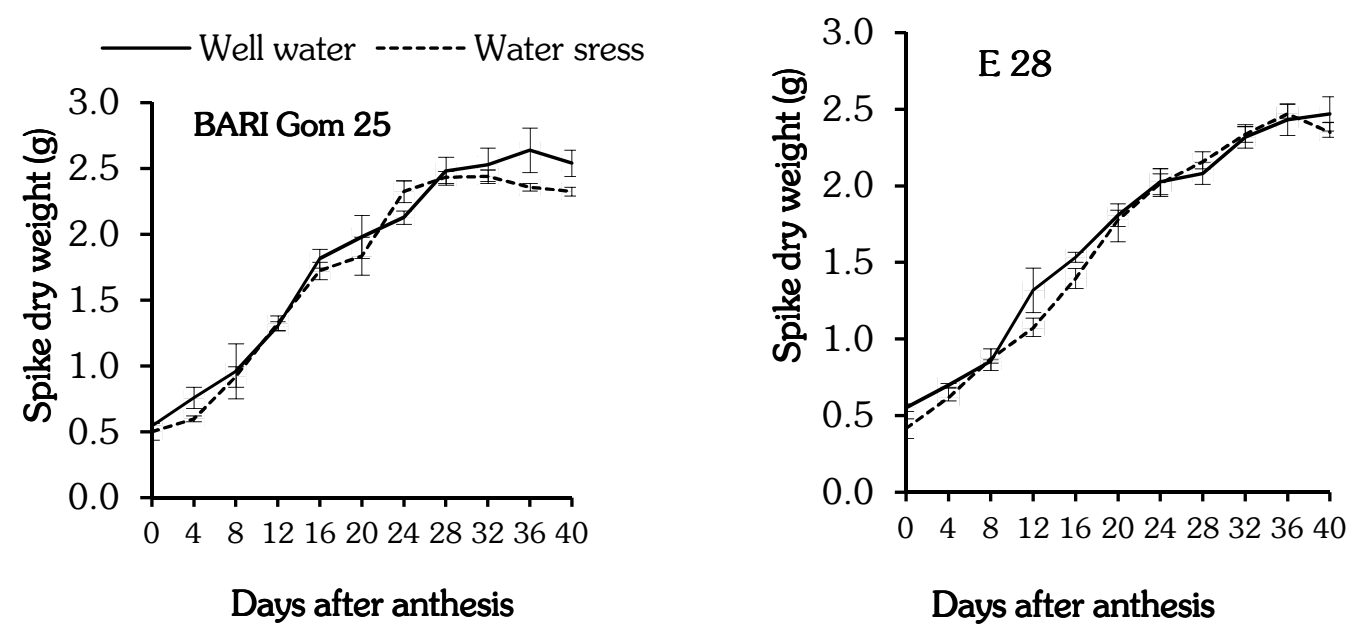

Days after anthesis
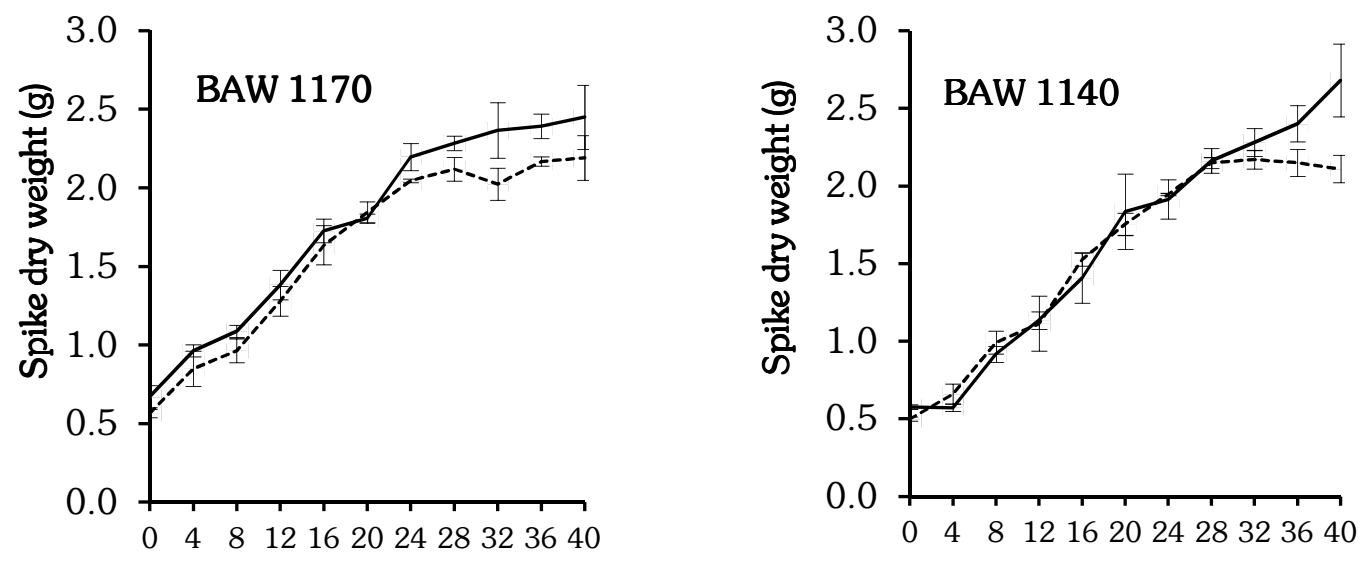

Days after anthesis

\section{Days after anthesis}

Fig. 2. Spike dry matter accumulation in different wheat genotypes at different days after anthesis as influenced by water regimes.

\section{Agronomic traits}

\section{Plant height}

Height of plant was not significantly influenced by the interaction effect of water regimes and wheat genotypes but all the wheat genotypes became shorter under water stress condition $(91.34 \mathrm{~cm}$ to $95.74 \mathrm{~cm})$ compared to that $(94.18 \mathrm{~cm}$ to $99.67 \mathrm{~cm})$ under well water condition (Table 4). In water deficit stress, plant suffers from physical drought and consequently the reduction in plant height was observed. Baque (2003) reported that water stress significantly reduced plant height. 
Rana et al.

\section{Spike length}

The interaction effect of water regimes and wheat genotypes on spike length was found significant (Table 4). At well water condition BARI Gom 25 produced the maximum length of spike $(12.96 \mathrm{~cm})$ which was followed by BAW $1170(11.13 \mathrm{~cm})$ and E $28(11.01 \mathrm{~cm})$ whereas BAW 1140 produced the shortest spike $(9.83 \mathrm{~cm})$. Due to water deficit stress spike length was reduced in all wheat genotypes. But the magnitude of reduction was not same for all wheat genotypes. The reduction was 16.51\% in BARI Gom 25, 2.70\% in E 28 and 5.49\% in BAW1170 and $6.84 \%$ in BAW 1140. Baque (2003) reported that ear length significantly reduced due to water deficit stress.

Table 4. Effect of water deficit stress on plant height and spike length of different wheat genotypes at harvest

\begin{tabular}{llcccc}
\hline \multirow{2}{*}{$\begin{array}{c}\text { Wheat } \\
\text { genotypes }\end{array}$} & Water regimes & \multicolumn{2}{c}{ Plant height } & \multicolumn{2}{c}{ Spike length } \\
\cline { 3 - 6 } & & $\mathrm{cm}$ & $\begin{array}{c}\% \text { change } \\
\text { over control }\end{array}$ & $\mathrm{cm}$ & $\begin{array}{c}\text { \% change } \\
\text { over control }\end{array}$ \\
\hline BARI Gom 25 & Well watered & 98.17 & - & $12.96 \mathrm{a}$ & - \\
& Water stress & 91.79 & -6.49 & $10.82 \mathrm{~b}$ & -16.51 \\
E 28 & Well watered & 94.18 & - & $11.01 \mathrm{~b}$ & - \\
\multirow{3}{*}{ BAW 1170 } & Water stress & 91.34 & -3.01 & $10.72 \mathrm{~b}$ & -2.70 \\
\multirow{2}{*}{ BAW 1140 } & Well watered & 99.67 & - & $11.13 \mathrm{~b}$ & - \\
& Water stress & 98.55 & -1.12 & $10.55 \mathrm{bc}$ & -5.49 \\
\hline Level of significance & Well watered & 96.96 & - & $9.83 \mathrm{~cd}$ & - \\
CV (\%) & Water stress & 95.74 & -1.25 & $9.20 \mathrm{~d}$ & -6.84 \\
\hline
\end{tabular}

In a column, values followed by similar letter(s) did not differ significantly by DMRT at $\mathrm{P} \leq 5 \%$

\section{Number of spikes $\mathrm{m}^{-2}$}

The combined effect of water regimes and wheat genotypes on number of spikes per $\mathrm{m}$ was significant (Table 5). Under well water condition, the maximum number of spikes per $m$ was observed in BAW 1140 (345) which was followed by E 28 (312) and BAW 1170 (287) whereas the lowest number of spikes per $m$ in BARI Gom 25 (263). Due to the effect of water deficit stress number of spikes per $\mathrm{m}$ was affected vigorously in all wheat genotypes. Under water deficit stress condition more reduction in number of spikes per $\mathrm{m}$ was observed in sensitive genotype (17.01\% in BAW 1140) compared to three tolerant genotypes (15.99\% in BARI Gom 25, 11.95\% in E 28 and 6.96\% in BAW 1170). Passioura (2007) also found 37\% reduction in spike $\mathrm{m}^{-2}$ when moisture stress was imposed during spike emergence and anthesis stage

\section{Number of grains spike $e^{-1}$}

Number of grains spike ${ }^{-1}$ was significantly influenced by the combined effect of water regimes and wheat genotypes (Table 5). Under well water condition, the maximum number of grains spike-1 was found in E 28 (46.67) which was followed by BARI Gom 25 (44.33) and BAW 1140 (43.33) whereas the lowest number in BAW 1170 (38.67). Due to the effect of water deficit stress number of grains spike ${ }^{-1}$ was reduced in all wheat genotypes. Under water deficit 
stress condition more reduction in number of grains spike $e^{-1}$ was observed in sensitive genotype (13.84\% in BAW 1140) compared to three tolerant genotypes $(6.76 \%$ in BARI Gom 25, $1.41 \%$ in E 28 and $2.65 \%$ in BAW 1170). Similar response of different wheat genotypes to different moisture levels was found by Shahram et al. (2003).

Table 5. Effect of water deficit stress on yield attributes of different wheat genotypes

\begin{tabular}{|c|c|c|c|c|c|c|c|}
\hline \multirow[t]{2}{*}{$\begin{array}{c}\text { Wheat } \\
\text { genotypes }\end{array}$} & \multirow[t]{2}{*}{$\begin{array}{l}\text { Water } \\
\text { regimes }\end{array}$} & \multicolumn{2}{|c|}{ Spikes $\mathrm{m}^{-2}$} & \multicolumn{2}{|c|}{ Grains spike ${ }^{-1}$} & \multicolumn{2}{|c|}{$\begin{array}{c}\text { 1000- grain } \\
\text { weight }\end{array}$} \\
\hline & & Number & $\begin{array}{c}\% \\
\text { change } \\
\text { over } \\
\text { control }\end{array}$ & Number & $\begin{array}{c}\% \\
\text { change } \\
\text { over } \\
\text { control }\end{array}$ & $\mathrm{g}$ & $\begin{array}{c}\% \\
\text { change } \\
\text { over } \\
\text { control }\end{array}$ \\
\hline \multirow[t]{2}{*}{ BARI Gom 25} & Well watered & $263 \mathrm{~d}$ & - & $44.33 \mathrm{ab}$ & - & 50.36 & - \\
\hline & Water stress & $221 e$ & -15.99 & $41.33 \mathrm{c}$ & -6.76 & 52.14 & +3.53 \\
\hline \multirow[t]{2}{*}{ E 28} & Well watered & $312 b$ & - & $46.67 \mathrm{a}$ & - & 38.46 & - \\
\hline & Water stress & $275 \mathrm{~cd}$ & -11.95 & $46.00 \mathrm{a}$ & -1.41 & 40.07 & +4.18 \\
\hline \multirow[t]{2}{*}{ BAW 1170} & Well watered & $287 c$ & - & $38.67 \mathrm{~d}$ & - & 41.91 & - \\
\hline & Water stress & $267 \mathrm{~cd}$ & -6.96 & $37.67 \mathrm{~d}$ & -2.65 & 44.34 & +5.79 \\
\hline \multirow[t]{2}{*}{ BAW 1140} & Well watered & 345 a & - & $43.33 \mathrm{bc}$ & - & 38.98 & - \\
\hline & Water stress & $268 \mathrm{~cd}$ & -17.01 & $37.33 \mathrm{~d}$ & -13.84 & 41.95 & +7.61 \\
\hline \multicolumn{2}{|c|}{ Level of significance } & *** & & $* *$ & & NS & \\
\hline \multicolumn{2}{|l|}{ CV (\%) } & 3.84 & & 3.16 & & 4.91 & \\
\hline
\end{tabular}

In a column, values followed by similar letter(s) did not differ significantly by DMRT at $\mathrm{P} \leq 5 \%$

\section{Thousand grain weight}

The interaction effect of water regimes and wheat genotypes on 1000-grain weight was not significant (Table 5). In general, all wheat genotypes provided greater grain size under water stress condition (40.07 to $52.14 \mathrm{~g} 1000$-grain $^{-1}$ ) compared to well water condition (38.46 to $50.36 \mathrm{~g} 1000$-grain $\left.^{-1}\right)$. Due to water deficit stress condition 1000-grain weight was increased in all genotypesmay be due to the reduction in grain number per spike which favors the larger grain size.

\section{Grain yield}

The combined effect of water regimes and wheat genotypes on grain yield was found significant (Table 6). Under well water condition, the maximum grain yield was recorded in BAW 1140 (4.22 t ha $\left.{ }^{-1}\right)$ which was followed by E 28 (3.89 t ha-1) and BARI Gom 25 (3.63 t $\left.\mathrm{ha}^{-1}\right)$ whereas the lowest in BAW 1170 (3.17 t ha-1).

Under water deficit stress condition more reduction in grain yield was observed in sensitive genotype (29.49\%\% in BAW 1140) compared to three tolerant genotypes (16.25\% in BARI Gom 25, 16.45\% in E 28 and 15.77\% in BAW 1170). Reduced number of spike per $\mathrm{m}$ and grains per spike were the major responsible factors for reducing the grain yield under water deficit stress condition. 
Rana et al.

\section{Above ground biological yield}

Above ground biological yield was influenced significantly by the combined effect of water regimes and wheat genotypes (Table 6). Under well water condition, the highest above ground biological yield was found in BAW 1140 (9.33 t ha'-1) which was followed by BARI Gom 25 (8.59 $\left.\mathrm{t} \mathrm{ha}^{-1}\right)$ and BAW $1170\left(8.27 \mathrm{t} \mathrm{ha}^{-1}\right)$ whereas the lowest in E $28\left(8.18 \mathrm{t} \mathrm{ha}^{-1}\right)$.

Due to water deficit stress above ground biological yield was reduced in all wheat genotypes. Under water deficit stress condition more reduction in above ground biological yield was observed in sensitive genotype (31.83\% in BAW 1140) compared to three tolerant genotypes (29.69\% in BARI Gom 25, 24.33\% in E 28 and 23.70\% in BAW 1170). The results are also in line with the findings of Wang et al. (2004).

Table 6. Effect of water deficit stress on grain and straw yield of different wheat genotypes

\begin{tabular}{|c|c|c|c|c|c|}
\hline \multirow{2}{*}{$\begin{array}{c}\text { Wheat } \\
\text { genotypes }\end{array}$} & \multirow[t]{2}{*}{ Water regimes } & \multicolumn{2}{|c|}{ Grain yield } & \multicolumn{2}{|c|}{ Biological yield } \\
\hline & & $\mathrm{t} \mathrm{ha}^{-1}$ & $\begin{array}{l}\% \text { change } \\
\text { over control }\end{array}$ & $\mathrm{t} \mathrm{ha}^{-1}$ & $\begin{array}{l}\text { \% change } \\
\text { over control }\end{array}$ \\
\hline \multirow[t]{2}{*}{ BARI Gom 25} & Well watered & $3.63 \mathrm{~b}$ & - & $8.59 \mathrm{~b}$ & - \\
\hline & Water stress & $3.04 \mathrm{c}$ & -16.25 & $6.04 \mathrm{c}$ & -29.69 \\
\hline \multirow[t]{2}{*}{ E 28} & Well watered & $3.89 \mathrm{~b}$ & - & $8.18 \mathrm{~b}$ & - \\
\hline & Water stress & $3.25 \mathrm{c}$ & -16.45 & $6.19 c$ & -24.33 \\
\hline \multirow[t]{2}{*}{ BAW 1170} & Well watered & $3.17 \mathrm{c}$ & - & $8.27 \mathrm{~b}$ & - \\
\hline & Water stress & $2.67 \mathrm{~d}$ & -15.77 & $6.31 \mathrm{c}$ & -23.70 \\
\hline \multirow[t]{2}{*}{ BAW 1140} & Well watered & $4.22 \mathrm{a}$ & - & $9.33 \mathrm{a}$ & - \\
\hline & Water stress & $3.06 \mathrm{c}$ & -27.49 & $6.36 \mathrm{c}$ & -31.83 \\
\hline \multicolumn{2}{|c|}{ Level of significance } & *** & & $*$ & \\
\hline \multicolumn{2}{|c|}{ CV (\%) } & 5.54 & & 3.64 & \\
\hline
\end{tabular}

In a column, values followed by similar letter(s) did not differ significantly by DMRT at $\mathrm{P} \leq 5 \%$

\section{Correlation analysis between relative performances of various parameters}

Correlation analysis between relative performances of various parameters studied in this investigation is presented in Table 7. Relative performance of grain yield maintained a significant positive correlation with the relative performance of flag leaf chl content at 24 DAA $\left(0.766^{* *}\right)$, relative flag leaf water content at 16 DAA $\left(0.584^{* *}\right)$, flag leaf proline content at 16 DAA $\left(0.904^{* *}\right)$, kernel proline content at 16 DAA $\left(0.813^{* *}\right)$, flag leaf soluble sugar content at 16 DAA $\left(0.730^{* *}\right)$, canopy temperature depression at 24 DAA $\left(0.704^{* *}\right)$ and above ground biological yield $\left(0.748^{* *}\right)$. 
Physiological Evaluation of Wheat Genotypes for Tolerance

Table 7. Relationship among the relative performances of physiological traits, grain yield and straw yield of different wheat genotypes

\begin{tabular}{|c|c|c|c|c|c|c|c|c|}
\hline Relationship & $\begin{array}{l}\text { Relative } \\
\text { flag leaf } \\
\text { chlorophyll } \\
\text { content at } \\
24 \text { DAA }\end{array}$ & $\begin{array}{l}\text { Relative } \\
\text { flag leaf } \\
\text { relative } \\
\text { water } \\
\text { content at } \\
16 \text { DAA }\end{array}$ & $\begin{array}{l}\text { Relative } \\
\text { flag leaf } \\
\text { proline } \\
\text { content at } \\
16 \text { DAA }\end{array}$ & $\begin{array}{l}\text { Relative } \\
\text { kernel } \\
\text { proline } \\
\text { content at } \\
16 \text { DAA }\end{array}$ & $\begin{array}{l}\text { Relative flag } \\
\text { leaf soluble } \\
\text { sugar } \\
\text { content at } \\
16 \text { DAA }\end{array}$ & $\begin{array}{l}\text { Relative } \\
\text { canopy } \\
\text { temperature } \\
\text { depression } \\
\text { at } 24 \text { DAA }\end{array}$ & $\begin{array}{l}\text { Relative } \\
\text { grain } \\
\text { yield }\end{array}$ & $\begin{array}{l}\text { Relative } \\
\text { above } \\
\text { ground } \\
\text { biological } \\
\text { yield }\end{array}$ \\
\hline $\begin{array}{l}\text { Relative flag leaf } \\
\text { chlorophyllcontent at } \\
24 \text { DAA } \\
\text { Relative flag leaf relative } \\
\text { water content at } 16 \text { DAA }\end{array}$ & $0.229 \mathrm{NS}$ & & & & & & & \\
\hline $\begin{array}{l}\text { Relative flag leaf proline } \\
\text { content at } 16 \text { DAA }\end{array}$ & $0.455^{*}$ & $0.814^{* *}$ & & & & & & \\
\hline $\begin{array}{l}\text { Relative kernel proline } \\
\text { content at } 16 \text { DAA }\end{array}$ & $0.300^{\mathrm{NS}}$ & $0.863^{* *}$ & $0.984^{* *}$ & & & & & \\
\hline $\begin{array}{l}\text { Relative flag leaf soluble } \\
\text { sugar content at } 16 \text { DAA }\end{array}$ & $0.345^{*}$ & $0.980^{* *}$ & $0.912^{* *}$ & $0.937^{* *}$ & & & & \\
\hline $\begin{array}{l}\text { Relative canopy } \\
\text { temperature depression at } \\
24 \text { DAA }\end{array}$ & $0.446^{*}$ & $-0.052^{N S}$ & $0.539^{* *}$ & $0.440^{*}$ & $0.147^{N S}$ & & & \\
\hline Relative grain yield & $0.766^{* *}$ & $0.584^{* *}$ & $0.904^{* *}$ & $0.813^{* *}$ & $0.730^{* * *}$ & $0.704 * *$ & & \\
\hline $\begin{array}{l}\text { Relative above ground } \\
\text { biological yield }\end{array}$ & $0.665^{* *}$ & $-0.090 \mathrm{NS}$ & $0.482^{* *}$ & $0.344^{*}$ & $0.111^{\mathrm{NS}}$ & $0.956^{* *}$ & $0.748^{* *}$ & \\
\hline
\end{tabular}


50

Rana et al.

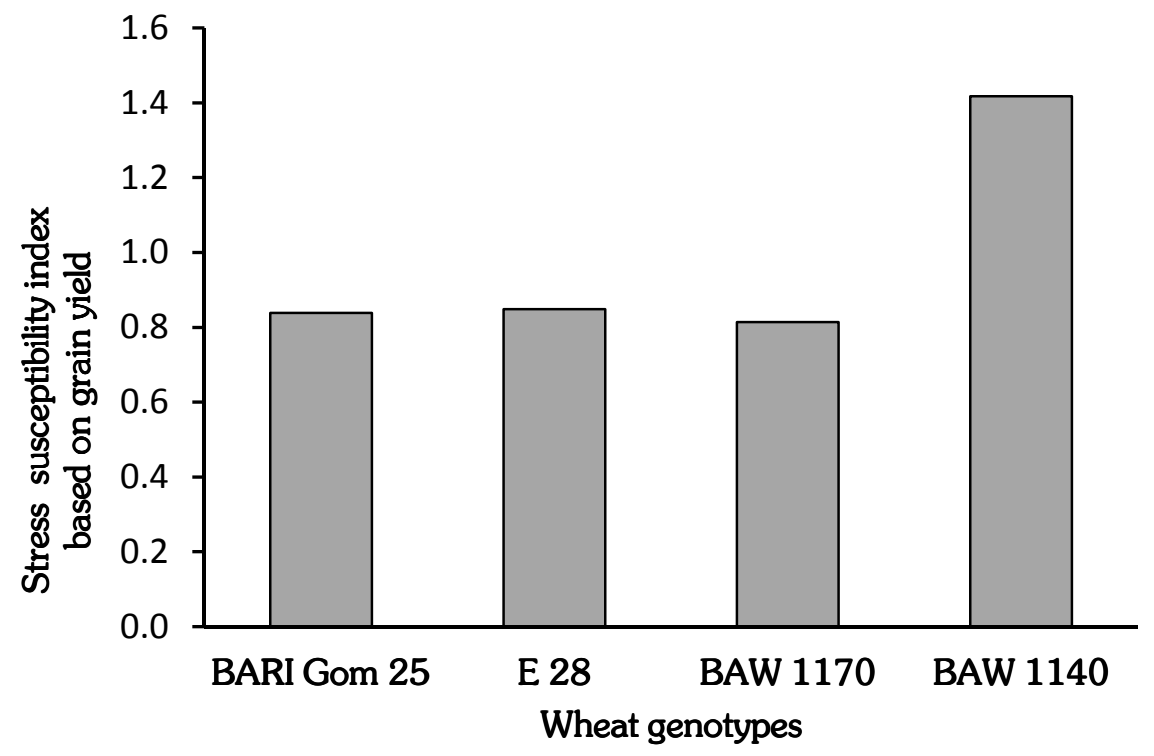

Fig. 3. Stress susceptibility index of different wheat genotypes based on grain yield.

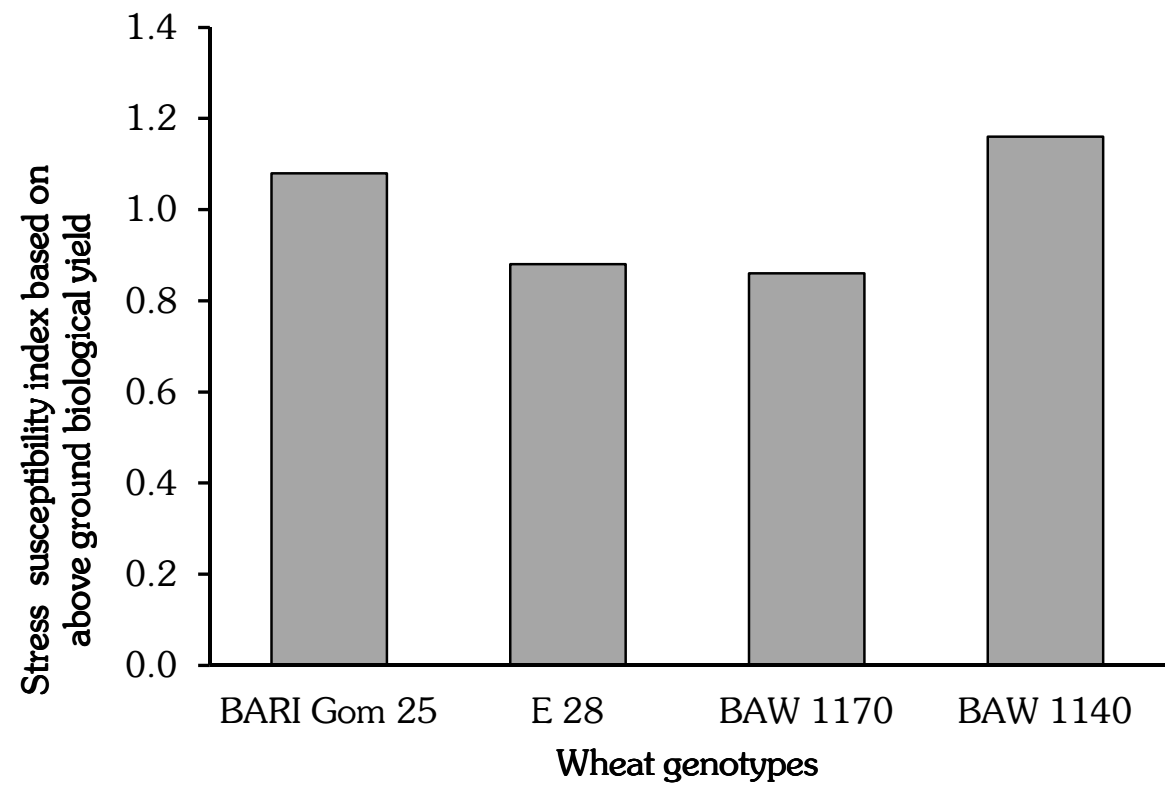

Fig. 4. Stress susceptibility index of different wheat genotypes based on above ground biological yield.

\section{Water stress susceptible index (SSI)}

Figure 3 shows stress susceptibility index of different wheat genotypes based on grain yield. BAW 1170 showed the lowest water stress susceptibility index (0.81) this was followed by BARI Gom 25 (0.84) and E 28 (0.85). BAW 1140 showed the highest water stress susceptibility index (SSI) value (1.42) (Figure 4). These stress susceptibility index values indicated 
that BAW 1170 was less susceptible genotype and BAW 1140 was the most susceptible genotype. Figure 4 also shows stress susceptibility index of different wheat genotypes based on above ground biological yield. The genotype BAW 1170 showed the lowest water stress susceptibility index (0.86) which followed by E 28 (0.88) and BARI Gom 25 (1.08). BAW 1140 showed the highest water stress susceptibility index (SSI) value (1.16). These stress susceptibility index values also indicated that BAW 1170 was less susceptible genotype and BAW 1140 was the most susceptible genotype.

\section{Conclusion}

Water deficit stress tolerant wheat genotypes showed greater stability of flag leaf chl, greater ability to retain water in leaf, higher level of proline in flag leaf and kernel, higher level of soluble sugar in flag leaf and greater ability to keep the canopy cooler compared to sensitive genotype under water deficit condition. Greater spike dry matter accumulation at peak, longer grain growth duration, better yield components such as spikes $\mathrm{m}^{-2}$ and grains spike ${ }^{-1}$ under water deficit stress contributed to better tolerance of BARI Gom 25, E 28 and BAW 1170.

The order of tolerance based on grain yield was BAW $1170>$ BARI Gom $25>$ E $28>$ BAW 1140 and the order of tolerance based on above ground biological yield was BAW $1170>\mathrm{E}$ 28 > BARI Gom 25 > BAW 1140.

\section{References}

Aggarwal, M., S. Sharma, N. Kaur, D. Pathania, and K. Bhandhari. 2011. Exogenous proline application reduces phytotoxic effects of selenium by minimising oxidative stress and improves growth in bean (Phaseolus vulgaris L.) seedlings. Biol. Trace Elem. Res. 140: 354-367.

Allakhverdiev, S. I., A. Sakamoto, Y. Nishiyama, M. Inaba and N. Murata, 2000. Ionic and osmotic effects of $\mathrm{NaCl}$-induced in activation of photo systems I and II in Synechococcus sp. Plant Physiol. 123: 1047-56.

Baque, M. A. 2003. Potassium induced changes in the physiology of wheat plants (Triticum aestivum L.) under water stress conditions. M.Sc.(Ag.) thesis, Dept Agron., Bangabandhu Sheikh Mujibur Rahman Agril. Univ., Gazipur.

Bayoumi, T. Y., M. H. Eid and E. M. Metwali. 2008. Application of physiological and biochemical indices as a screening technique for drought tolerance in wheat genotypes. Afr. J. Biotechnol. 7: 2341-2352.

BBS, 2016. Yearbook of agricultural statistics of Bangladesh, Bangladesh Bureau of Statistics, Ministry of planning, Government of the people's Republic of Bangladesh. $47 \mathrm{p}$.

Blum, A., L. Shipiler, G. Golan and J. Mayer. 1989. Yield stability and canopy temperature of wheat Osmotic adjustment and growth of barley genotypes under drought stress. Crop Sci. 29:230-233.

Buttar, G. S., C. J. Singh, M. S. Ahuja and K. S. Saini. 2005. Canopy temperature: A method to estimate plant water stress and scheduling irrigation in cotton and wheat. J. Agric. Physics. 5(1): 79-83. 
Rana et al.

Chandrasekar, V., R. K. Sairam and G. C. Srivastava. 2000. Physiological and biochemical responses of hexaploid and tetraploid wheat to drought stress. J. Agron. Crop Sci. 185: 219-227.

Deora, V. S., M. A. A. Shah and A. Joshi. 2001. Effect of moisture stress on wheat genotypes. Crop, Research, Hisar. 21(1):24-26.

Farshadfar, E., M. Ghasemi and F. Rafii. 2014. Evaluation of physiological parameters as a screening technique for drought tolerance in bread wheat. J. Biodiv. Environ. Sci. 4: 175186.

Hasan, M. A., J. A. Ahmed, M. M. Bahadur, M. M. Haque and S. Sikder. 2007. Effect of late planting heat stresss on membrane thermostability, proline content and heat susceptibility index of different wheat cultivars. J. Nat. Sci. Foun. Srilanka 35(2): 109-117.

Hasheminasab, H., M. T. Assad, A. Aliakbari and S. R. Sahhafi, 2012. Evaluation of some physiological traits associated with improved drought tolerance in Iranian wheat. Ann. Biol. Res. 2012;3:1719-1725.

Kameli, A. and D. M. Loesel. 1993. Carbohydrates and water status in wheat plants under water stress. New Phytol. 125: 609-614.

Karim M. A., A. Hamid and S. Rahman. 2000. Grain growth and yield performance of wheat under subtropical conditions: II. Effect of water stress at reproductive stress. Cereal Res. Comm. 28: 101-107.

Khakwani, A. A., M. D. Dennett, M. Munir and M. Abid. 2012. Growth and yield response of wheat varieties to water stress at booting and anthesis stages of development. Pak. J. Bot., 44(3): 879-886.

Kiliç, H. and T. Yagbasanlar. 2010. The effect of drought stress on grain yield, yield components and some quality traits of durum wheat (Triticum turgidum ssp. durum) cultivars. Not. Bot. Hort. Agrobot. Cluj 38 (1): 164-170.

Motzo, R., F. Giunta and M. Deidda. 1996. Relationships between grain filling parameters, fertility, earlines and grain protein of durum wheat in a Mediterranean environment, Field Crops Res. 47: 129-142.

Muller, A. G., 2001. Modelagem da matéria seca e do rendimento de grãos de milho em relação à disponibilidade hídrica. Tese Doutorado em Fitotecnia . Porto Alegre.

Nayyar, H. and D. Gupta. 2006. Differential sensitivity of C3 and C4 plants to water deficit stress: Association with oxidative stress and antioxidants. Environ. Exp. Bot. 58: 106-113.

Passioura, J. B., 2007. The drought environment: Physical, biological and agricultural perspectives. J. Expt. Bot. 58(2): 113-117.

Shahram, M. D., K. Moore and J. Ollerenshaw. 2003. Qualitative inheritance of water stress induced apical sterility in wheat (Triticum aestivum L.). Hereditas. 138: 237-240.

Sial, M. A., M. U. Dahot, M. A. Arain, G. S. Markhand, M. H. Naqvi, K. A. Laghari and A. A. Mirbahar. 2009. Effect of water stress on yield and yield components of semi-dwarf bread wheat (Triticum aestivum L.). Pak. J. Bot. 41 (4): 1715-1728.

Yoshida, S., D. A. Forno, J. H. Cpck and K. A. Gomez. 1976. Laboratory Manual for Physiological Studies of rice (Third edition).The International Rice Research Institute, Los Banos, Laguna, Philipines. pp. 46-49. 